\title{
The Impact of Short-Form Content Types and Use of Motivation on Content Consumption of Youth
}

\author{
솟폼 콘텐츠 유형과 청소년의 이용 동기가 \\ 콘텐츠 소비에 미치는 영향
}

Hyun Joong $\mathrm{Yu}^{1}$, Hae Won Chung ${ }^{2}$

유현중 ${ }^{1}$, 정해원 ${ }^{2}$

${ }^{1}$ Professor, Politics \& Communication Department, Hannam University, Korea, yhj1075@paran.com

${ }^{2}$ Professor, Advertising \& PR Department, Kosin University, Korea, lamerun@naver.com

Corresponding author: Hae Won Chung

\begin{abstract}
This study is aimed at examining what content is consumed according to the type of shortform, which is currently the most popular content type. Furthermore, the study also examined if the type of short form platform is affecting the content theme and the consumption of such content is varied. A survey of 218 teenagers (108 men and 110 women) who consume a lot of short form contents was conducted on high school students in Busan. The researchers wanted to discover if the motivation for content consumption can affect sustainability and verbal use. As a result, according to the first type of shortform, the content consumption was looked at in the order of YouTube(Shorts) $>$ Instagram(Reels) $>$ Facebook (Watch) $>$ TikTok. There were also differences in gender. Various topics were appearing for each platform type. The second factor analysis was used to extract the factors for use motivation and use satisfaction. Results on motivation for use (fun, usefulness, ease of use) and satisfaction (use continuity, reliability, oral intention) both showed statistically significant results. Thirdly, the results of the analysis on inconvenience and satisfaction of use showed significant results only in oral effects. By analyzing differences in shortform content at a time when it is currently being serviced on all major platforms, it was possible to predict the shortform content market that is in full swing in the future. In addition, differences in usage by gender and theme could be found depending on the shortform platform, which could provide an important guide line when establishing advertising strategies.
\end{abstract}

Keywords: Short-Form, Short-Form Platform, Use and Gratification, Contents Consumption, Motivation, Youth

요약: 본 연구는 솟폼 유형에 따라 어떠한 콘텐츠를 소비하는지 살펴보기 위한 연구로 현재 가장 유행하고 있는 콘텐츠 유형별로 이를 살펴보았다. 숏폼 플랫폼의 유형이 콘텐츠 테마에 영향을 미치고 있으며 이러한 콘텐츠 소비가 다양하게 이뤄지고 있는 것인지 살펴보고자 하였다. 이를 위하여 숏폼 콘텐츠를 많이 소비하는 부산지역 10대 고등학생 218명(남자108명, 여자 110 명)을 대상으로 조사를 실시하였다. 콘텐츠 소비에 있어 어떠한 이용동기가 사용지속과 구전에 영향을 미칠 수 있다는 점을 밝혀보고자 하였다. 그 결과 첫 번째 숏폼 유형에 따라 콘텐츠 소비 빈도를 비교 분석한 결과 유튜브(Shorts)> 인스타그램(Reels)>

Received: March 29, 2021; 1st Review Result: May 12, 2021; 2nd Review Result: June 25, 2021 Accepted: July 31, 2021 
페이스북(Watch)> 틱톡(TikTok)순으로 나타나고 있었다. 또한 성별에 따른 차이도 다르게 나타나고 있었다. 각 플랫폼 유형별로 소비하는 주제가 다양하게 나타나고 있었다. 두 번째는 요인분석을 통해 이용 동기와 이용 만족에 대한 요인을 추출하였다. 이용 동기(재미, 유용성, 용이성)와 이용 만족(이용지속, 신뢰성, 구전의도)에 대한 결과는 모두 통계적으로 유의미한 결과가 나타났다. 세 번째로 이용 불편과 이용 만족에 대한 분석결과는 구전효과에서만 유의미한 결과가 나타났다. 현재 모든 주요 플랫폼에서 서비스하고 있는 시점에서 솟폼 콘텐츠의 차이를 분석함으로써 향후 본격화되고 있는 솟폼 콘텐츠 시장을 전망할 수 있었다. 그리고, 솟폼 플랫폼에 따라 성별, 테마별로 이용의 차이를 발견할 수 있었으며 이는 광고전략 수립 시 중요한 가이드 라인을 제시할 수 있을 것이다.

핵심어: 솟폼, 솟폼 플랫폼, 이용동기, 콘텐츠 소비

\section{1. 서론}

\section{1 연구배경 및 목적}

짧은 콘텐츠가 유행되는 세상이다. 많은 젊은 세대들이 콘텐츠를 즐기고 이를 통해 정 보를 얻고 있다. 모바일을 통해 다양한 플랫폼을 이용하여 콘텐츠를 소비하고 있다. 그런 데 이러한 콘텐츠의 길이는 점점 짧아지고 있다. 15초 이내의 동영상을 보여주는 TikTok 이 $\mathrm{Z}$ 세대를 중심으로 인기를 끌며 숏폼 콘텐츠가 문화 트랜드의 주류로 정착하고 있는 셈이다. '숏폼 콘텐츠'는 글자 그대로 짧은 길이의 영상을 의미하며 몇 초에서 10 분 이내 의 영상까지 그 종류는 매우 다양하다. 그런데 이러한 숏폼 콘텐츠는 $\mathrm{Z}$ 세대에게 선호도 가 높아지면서 기업의 마케팅 활동을 위한 광고 역시 그 길이가 짧아지면서 변화를 가져 오고 있다. 솟폼 전문 플랫폼이 글로벌 시장을 중심으로 움직이면서 구글, 인스타그램과 같은 글로벌 IT기업들이 손쉽게 콘텐츠 제작이 가능한 툴 및 서비스를 제공하고 있다. 국 내에서도 기존의 방송이나 동영상 플랫폼을 통한 마케팅용 숏폼 콘텐츠 서비스가 활성화 되고 있는 실정이다. 기존의 롱폼 콘텐츠는 $\mathrm{TV}$ 를 통한 방송 영상이라면 디지털 네이티브 인 Z세대에게는 모바일을 통한 짧은 숏폼 콘텐츠를 통해 이를 소비하고 있는 셈이다. 숏 폼 콘텐츠는 2018년 Z세대를 중심으로 문화 트렌드로 자리 잡았는데 Tik Tok의 어플리케 이션이 그 중심에 있었다고 할 것이다. 15 초 내외의 짧은 동영상을 유저 본인이 촬영하고 편집하여 이를 공유하고 소비함으로써 시간이 날 때마다 모바일을 통하여 이를 전파하고 있다. 모바일 디바이스의 대중화가 콘텐츠 소비의 패턴을 변화시켰다고 할 수 있을 것이 다. 이동 및 쉬는 시간에 모바일 기기로 동영상을 시청하기 때문에 잡고 간결한 형태인 숏폼 콘텐츠의 소비가 증가했다고 할 수 있을 것이다. 이러한 Z세대의 숏폼 콘텐츠의 선 호는 자기 PR을 위한 도구로 혹은 하나의 놀이로 자리잡고 있다. 또한 이러한 추세는 연 령이 낮을수록 20 분 미만의 콘텐츠를 선호하며 10-20대의 선호 동영상 길이는 15 분 이내 로 나타나고 있다[1]. 숏폼 콘텐츠 플랫폼인 틱톡의 10 대 유저 비율은 $42.7 \%$ 를 차지하고 있을 정도로 높은 비중으로 나타나 있다. 국내 솟폼 콘텐츠 활성화는 기존 방송, 동영상 플랫폼을 통한 마케팅(광고) 솟폼 콘텐츠 서비스가 활성화 되었다.

마케팅을 위한 수단으로 또한 새로운 콘텐츠를 위한 홍보 수단으로 숏폼 콘텐츠의 인 기는 날로 높아지고 있으며 앞으로도 다양한 플랫폼을 통해 이러한 현상이 지속될 것으 로 보여진다. 때문에 이러한 솟폼 콘텐츠를 통해 소통하는 많은 MZ세대를 위한 전략적 
제안을 위해 이런 숏폼 콘텐츠를 이용하는 이용 동기와 몰입이 무엇이며 어떠한 콘텐츠 를 주로 소비하고 있는지 살펴보고자 한다.

\section{2. 솟폼 콘텐츠의 이론적 배경}

\section{1 솟폼 콘텐츠의 개념과 정의}

온라인 플랫폼을 기반으로 하는 솟폼 형식의 동영상 콘텐츠는 기존 방송 콘텐츠들의 주요 내용을 편집한 방송 영상들이 포털사이트에서 제공되기 시작하면서 등장했다. 클립 동영상(clip video), 쇼트 클립(short clip), 쇼트 동영상(short video), 솟폼 동영상(short form video) 등 다양한 단어들이 혼재된 채 사용되고 있다. 즉, 숏폼이라는 개념은 동영상 콘텐츠의 형식적 특성을 지칭하기보다는 전통적인 롱폼 콘텐츠인 드라마나 예능과 같은 텔레비전 콘텐츠나 영화의 파라텍스트(paratext)로 인식되어 왔다. 파라텍스트는 제라르 주네트(Gérard Genette)가 제시한 개념으로 텍스트의 '문턱(threshold)'에 위치해 주텍스트를 보완하는 다양한 형식의 부가텍스트를 의미하는 개념이다[2]. 솟폼 동영상 콘텐츠는 예고나 쿠키 영상과 같은 프롤로그와 에필로그 형태나 핵심 장면들을 압축적으로 집약한 하이트라이트 영상 등을 통상적으로 지칭하는 단어라 할 수 있다. 주텍스트에서 가장 흥미로운 부분을 압축적으로 보여주는 예고나 방송 영상이 주텍스트에 대한 호기심을 불러일으키는 부가텍스트로 볼 수 있다면, 모바일 환경에서 방송 영상은 본 콘텐츠의 대체제로 소비되기도 한다. 나아가 모바일 플랫폼을 기반으로 생산의 측면에서 상시적인 제작과 공유가 가능해지고, 소비의 측면에서 스트리밍 중심의 향유가 일반화되면서 솟폼은 동영상 콘텐츠의 한 형식으로 자리 잡았다. 본 연구에서는 사용자의 다층적 이동성을 바탕으로 등장한 솟폼 형식 콘텐츠 중, 동영상 형태의 콘텐츠를 통칭 솟폼 동영상 콘텐츠(short-form video contents)로 지칭하고자 한다. 전통적인 롱폼 동영상 콘텐츠의 형식을 규정했던 텔레비전 편성이나 극장 상영과 같은 공급과 향유의 통로가 다변화된 것에 기인해 솟폼 동영상 콘텐츠는 내용적인 측면에서 다양한 스펙트럼을 보여준다. 영화, 드라마, 예능, 다큐멘터리 등 기존의 롱폼 동영상 콘텐츠의 서사적 특성들을 수용하는 동시에 기존의 롱폼 콘텐츠에서 할 수 없었던 장르의 융합이나 재구성이 활발히 이루어지고 있다. 사용자에 의해 만들어지고 공유되는 콘텐츠까지 그 범위를 확장하면 전통적인 롱폼 콘텐츠 위주로 정립된 장르를 적용하는 것이 무의미할 정도다. 즉, 솟폼 동영상 콘텐츠의 특성을 파악하기 위해 플랫폼 중심의 콘텐츠를 어떠한 목적으로 사용하는지 그 동기에 기인하는 이유를 찾아내는 것이 바람직할 것으로 보인다.

\section{2 솟폼 플랫폼의 유형과 특징}

솟폼 플랫폼은 2016년 중국의 IT회사 바이트 댄스에서 출시하였으며, 2017년 9월부터 틱톡(TikTok)이라는 명칭을 사용하였으며, 같은 해 11월 미국의 솟폼 영상 제작 앱 ‘뮤지 컬리'를 10 억 달러에 인수 및 통합 후 전 세계적인 인기를 얻었다. 초기에 킬링 타임용 15 초 짜깁기 영상이라는 비판을 받았다. 그러나 다른 SNS 서비스와 달리 '팔로잉'이나 ‘친구, 같은 관계 형성에 대한 부담이 없으며 단지 가볍게 즐기는 재미있는 콘텐츠 소비 가 서비스의 핵심으로 앱을 통한 간단한 동영상 제작과 다양한 배경음악의 무료 사용이 큰 특징이라고 할 수 있다. Z세대가 틱톡에 열광하는 이유는 그들이 제품 서비스를 선택 
할 때 재미를 최우선 요건으로 고려하는 '펀슈머(Fun-sumer)'이기 때문이다.

인스타그램 Reels는 페이스북에서 만든 숏폼 플랫폼으로 형식은 틱톡과 비슷한 형태를 가지고 있다. 15 초가량의 짧은 비디오 형식에서부터 음악 및 텍스트 편집기능, 화려한 특 수효과등이 그대로 적용되어 틱톡이 연상된다는 비판을 받았다. 사용자는 업로드한 숏폼 콘텐츠를 스토리나 다이렉트메시지(DM)에 공유할 수 있으며, 지인에게만 노출되는 것이 아닌 탐색 탭에서 ‘Top Reels'라는 섹션을 통해 다른사람에게 추천 콘텐츠로 보이기도 한 다.

유튜브가 인도시장을 시작으로 솟폼 동영상 플랫폼을 진출했다. Shorts로 최대 60 초 길 이를 지원하는 세로 동영상 플랫폼으로 동영상 제작도구인 '쇼츠 카메라'를 통해 촬영이 가능하고 60 초 미만의 동영상을 자유롭게 업로드 할 수 있도록 지원한다. 다만 쇼츠 카 메라를 통해 촬영한 영상은 틱톡보다 더 짧은 15 초 길이의 영상만을 담을 수 있다.

페이스북의 새로운 동영상 플랫폼인 Watch는 2017년 8월 출시되었다. 페이스북 친구를 초대해 영상을 함께 감상하는 워치파티(Watch Party), 설문조사를 진행할 수 있는 폴(Poll), 페이스북 그룹에 영상을 공유하는 워치 그룹 등 다양한 기능이 있다. 사용자의 행동을 중심으로 네트워크를 공유하는 동영상 플랫폼으로 소셜네트워크의 강점인 개인화와 커뮤 니케이션 기능을 동영상에 엮어내어 소통 가능한 동영상 플랫폼 형태를 제시하고 있다. Quibi는 디즈니 스튜디오 전 회장이 숏폼 플랫폼을 만들어서 넷플릭스와 경쟁한다는 이 야기를 했던 곳으로 런칭전에 디즈니, 알리바바, JP모건 등 대기업에게 2조원의 투자금을 끌어모아 화제를 모았다.

네이버가 모바일에서 1분만에 만드는 솟폼 에디터 '블로그 모멘트(MOMENT)'를 선보 였다. 손가락으로 가볍게 터치만 하면 다양한 스타일이 적용된 영상이 완성되고, 여기에 네이버만의 서비스인 지도, 예약, 쇼핑, 플레이스 등을 동영상에 담을 수 있다.

\section{3 콘텐츠 이용을 위한 이용과 충족 이론}

이용과 충족이론은 이용자 측면에서 미디어 이용을 고찰하려 했다. '매스미디어가 사람 들에게 무엇을 하고 있느냐'는 입장에서 벗어나 '사람들이 매스미디어를 가지고 무엇을 하느냐는 관점'에서 커뮤니케이션 현상을 연구하는 이론이다[3]. 즉 이용자는 구체적인 동기를 가지고 자신의 욕구를 충족시켜줄 특정 미디어를 의도적으로 선택하여 소비한다 는 것이다[4]. 이러한 미디어 선택과 이용을 설명해주는데 있어 이용과 충족은 매스미디 어 이용자의 심리적 필요나 욕구로 인해 특정 미디어 이용을 분석하고 이용결과로 인해 심리적 욕구가 어떻게 충족되는가를 설명할 수 있다는 것이다. 전통적인 이용과 충족 연 구에 의하면 이용자들은 정보추구, 여가선용, 현실도피와 같은 심리적 욕구를 채우기 위 한 방법으로 미디어를 이용한다는 것이다. 이처럼 이용자에 초점을 맞추어 사회심리학적 접근을 통해 이용과 충족 이론은 사람들의 욕구 및 필요와 관련된 미디어 이용을 설명함 에 따라 심리적 동기에 따른 이용행위를 강조한다. 블룸러(Blumler, 1979)는 동기와 관련하 여 3 가지를 제시하였다[5]. 정보추구 및 획득을 위한 인지적 동기, 둘째 기분전환 및 현실 도피와 관련된 오락적 동기, 셋째 강화 효과를 초래하는 개인적 정체성 동기이다. 카츠, 구레비치와 하스(Katz, Gurevitch, \& Hass, 1973)는 동기 요인을 다섯 가지 유형의 욕구로 분 류하였다[6]. 첫째 정보검색 및 환경이해 강화와 관련된 인식적 욕구, 둘째 심미적, 오락 적, 감성적, 경험 강화와 관련된 감정적 욕구, 셋째 신뢰, 자신감, 안정감, 개인적 지위, 강화와 관련된 개인 통합적 욕구, 넷째 가족 친구, 사회교류 강화를 사회 통합적 옥구, 
다섯째 현실도피, 긴장완화, 기분전환과 관련된 현실도피 욕구는 동기 용인을 규명하는 미디어 연구의 근간을 만들었다. 이용동기를 밝히는 연구에서 콘텐츠의 특성에 상관없이 사용자의 콘텐츠 이용 동기가 유사하게 나타난 연구도 있었지만, 콘텐츠의 특성이 반영 되어 서로 다르게 나타난 이용 동기도 존재했다. 먼저, 뉴스 이용 동기를 연구한 기존 문 헌에 따르면, 뉴스 콘텐츠 이용 동기로는 여가 추구, 정보 추구, 편리성, 의견 교환, 오락 성, 상호작용성, 전문성, 최신성, 뉴스 공정성으로 나타났다[7]. 음악 콘텐츠의 이용 동기 로는 오락성, 현실도피, 대인 관계, 집중성, 사회적 관계, 흥미성, 시간 때우기, 가사에 대 한 정보성, 기분전환, 외로움 등으로 나타났다[8]. 마지막으로 영상 이용 동기들로는 상호 작용성, 습관적 소비성, 시간 때우기, 쾌락성, 성적 흥미, 오락과 휴식, 정보 취득, 팬덤 현상 그리고 사회적 실재감 등이 나타났다[9]. 요약해 보면, 뉴스, 음악, 영상 콘텐츠는 공 통적으로 흥미성, 대인 관계(의견 교환), 정보 추구, 여가 추구(시간 때우기)의 이용 동기 가 있었지만, 뉴스의 경우에는 전문성, 뉴스 가치, 공정성의 이용 동기가 차별적인 이용 동기였고, 음악의 경우에는 현실도피, 집중성, 외로움의 동기가 음악의 차별적인 이용 동 기로 나타났다. 그리고 동영상의 경우에는 사회적 실재감, 팬덤 현상이 다른 콘텐츠와는 차별적인 이용 동기로 나타났다.

\section{4 솟폼 콘텐츠 속성에 따른 이용자 만족}

숏폼 콘텐츠 속성에 있어 유용성을 논의 할 수 있을 것이다. 유용성은 이용자들이 플 랫폼에서 정보를 얻는 과정에서 효율적이고 효과적인 도움을 얻을 수 있다고 이용자가 인식하는 정도라고 볼 수 있다[10]. 용이성은 필요한 정보를 사용하는데 이용자에게 쉽다 고 여겨지는 정도라고 할 수 있다 이처럼 콘텐츠 사용에 있어 유용성과 용이성은 숏폼 콘텐츠를 이용하는데 있어 직접적인 영향을 미친다고 볼 수 있다. 지각된 유용성과 용이 성이 숏폼 콘텐츠를 이용하는데 있어 이용의도에 영향을 미칠 수 있으며 실제로 이용자 들이 콘텐츠를 이용함에 있어 이러한 점이 매우 중요하게 작용할 수 있을 것이다. 실제 로 기존의 연구에서 SNS 이용자들을 대상으로 한 연구에서 SNS 서비스 속성인 지각된 유용성과 상호작용이 SNS에 대한 신뢰를 형성하는데 영향을 미치고 있다고 보았다. 또한 콘텐츠의 재미 요인은 만족과 사용 의도에 긍정적인 영향을 미칠 수 있다고 하였다[11]. 이처럼 지각하는 재미 요인과 상호작용에 영향이 이용자에게 만족을 느낄 수 있는 요인 으로 작용할 수 있을 것이다. 이와 관련하여 이용자의 만족은 Babin and Griffin(1994)의 연 구에서 일련의 경험에 대한 평가의 결과로 유발되는 정서적 반응이라고 하였다[12]. 이러 한 만족에 대한 평가는 지속적인 사용과 함께 구전의도를 가지고 있는가에 대한 행동적 반응을 통해 이를 확인할 수 있을 것이다.

\section{3. 연구방법 및 연구가설}

\section{1 연구범위 및 방법}

솟폼 콘텐츠를 가장 많이 소비하고 있는 10 대를 통해 어떤 이유로 솟폼 콘텐츠를 이 용하고 있으며, 주로 소비하는 콘텐츠는 무엇인지 확인하기 위해 다음과 같이 살펴보았 다. 2020년 5월 10 일부터 20일까지 17세에서 19세까지의 부산의 고등학생 230명(남녀 각 각 115 명씩)에게 콘텐츠 소비와 관련된 설문을 통해 응답하게 하였다. 응답자의 표본은 편의표본 추출방법에 의해 표본을 선정하였으며, 이 중 불성실한 응답을 제외하고 총 
218명(남자 108 명, 여자 110 명)에게 응답을 받았다. 콘텐츠 이용 동기와 이용만족 그리고 콘텐츠 소비를 통해 어떤 이유에서 솟폼 콘텐츠를 이용하고 있는지 또 주로 소비하는 콘 텐츠는 무엇인지 각각의 플랫폼을 통해 이를 확인하고자 하였다. 먼저 콘텐츠 이용과 관 련한 다양한 플랫폼들에 대한 이용과 함께 솟폼 콘텐츠에 대한 인식 그리고 주로 소비하 는 숏폼 콘텐츠에 대해 살펴보고 이를 바탕으로 이용동기와 이용만족에 대한 요인을 통 해 이용지속과 신뢰성, 구전의도에 대해 살펴보았다. 그리고 숏폼 콘텐츠의 이용을 저해 하는 이용 불편성이 이용만족에 영향을 미치는지 살펴보고자 하였다.

가설 1 : 숏폼 플랫폼의 유형에 따른 콘텐츠 테마는 차이가 있을 것이다

가설 2 : 숏폼 콘텐츠의 이용 동기에 따른 이용 만족(이용지속, 신뢰성, 구전의도)은 차 이가 있을 것이다

가설 3 : 솟폼 콘텐츠의 이용 불편성은 이용만족(이용지속, 신뢰성, 구전의도)에 차이가 있을 것이다.

\section{2 설문지의 구성}

설문의 구성을 주로 사용하는 플랫폼 유형(TikTok, Shorts, Reels, Watch)에 따라 주로 이 용하는 솟폼 콘텐츠를 살펴보았고, 이러한 콘텐츠의 이용 동기 요인의 11 문항, 이용 만족 13 문항으로, 총 24 문항으로 구성하였다. 그리고 솟폼 콘텐츠를 이용하는데 있어 불편한 정보이용과 관련된 3 문항을 통해 이를 살펴보았다. 플랫폼에서 정보를 이용하는데 있어 불필요한 광고, 이용에 있어 어려움, 불필요한 정보등의 내용이 콘텐츠 이용에 불편함을 줄 수 있다는 것으로 이러한 내용을 통해 이용만족에 어떠한 영향을 주는지 살펴보고자 하였다.

본 연구의 숏폼 콘텐츠의 이용 동기를 살펴보기 위해 소셜미디어의 이용동기 연구를 통해 본 연구에 맞게 수정하였다. 재미 요인은 Henderson, Glancy, Little(1999)의 연구에서 측정항목을 통해 수정하였으며[13], 유용성과 용이성 요인은 Craig, Ross, Emily(2009)의 연 구를 통해 이를 재구성하였다[14]. 그리고 이용 만족의 항목은 Moore and Benbasat(1991)의 측정도구를 재구성하여 사용하였다[15]. 숏폼 콘텐츠를 통한 이용 만족에 대한 문항은 사 용에 대한 지속으로 행동적 의도가 있는가를 측정하는 문항으로 구성하였으며, 구전 의 도는 타인의 긍정적인 행동을 이끌어내고자 하는 것으로, 선행연구를 바탕으로 5 점 척도 로 구성하였다.

\section{3 자료의 처리}

자료 분석 방법으로는 데이터 코딩과 데이터 스크리닝을 거쳐 SPSS 21.0 프로그램을 활 용하여 분석하였으며, 다음과 같은 절차를 거쳤다. 첫째, 숏폼 콘텐츠 플랫폼 유형에 따 른 다중응답 분석 결과를 통해 성별로 교차 분석을 실시하였으며, 둘째 이용동기, 이용만 족 등의 타당성 검증을 위해 요인분석을 실시하였으며, 신뢰도 검증을 위해 Cronbach's $\alpha$ 계수를 산출하였다. 셋째 이용불편이 이용만족에 미치는 영향을 알아보기 위해 단순회귀 분석을 실시하였다. 


\section{4. 연구결과}

\section{1 가설 1 의 결과}

숏폼 콘텐츠를 주로 소비하는 플랫폼에 대한 결과는 다음과 같다

[표 1] 성별에 따른 숏폼 플랫폼 교차 분석 결과(다중응답)

[Table 1] Result of Cross Analysis on Shortform Platforms by Gender (Multiple Responses)

\begin{tabular}{c|c|c|c|c|c|c|c}
\hline 유형 & $\begin{array}{c}\text { 유튜브 } \\
\text { (Shorts) }\end{array}$ & $\begin{array}{c}\text { 페이스북 } \\
\text { (Watch) }\end{array}$ & $\begin{array}{c}\text { 인스타그램 } \\
\text { (Reels) }\end{array}$ & $\begin{array}{c}\text { 틱톡 } \\
\text { (TikTok) }\end{array}$ & $\begin{array}{c}\text { 네이버 } \\
\text { 블로그 } \\
\text { (MOMENT) }\end{array}$ & $\begin{array}{c}\text { 기타 } \\
\text { (Quibi) }\end{array}$ & 합계 \\
\hline 남 & $103(47.2 \%)$ & $55(25.2 \%)$ & $58(26.6 \%)$ & $35(16.1 \%)$ & $7(3.2 \%)$ & $11(5.0 \%)$ & $108(48.5 \%)$ \\
\hline 녀 & $106(48.6 \%)$ & $18(8.3 \%)$ & $89(40.8 \%)$ & $37(17.0 \%)$ & $13(6.0 \%)$ & $13(6.0 \%)$ & $110(50.5 \%)$ \\
\hline 합계 & $209(95.9 \%)$ & $73(33.5 \%)$ & $147(67.4 \%)$ & $72(33.0 \%)$ & $20(9.2 \%)$ & $24(11.0 \%)$ & $218(100.0 \%)$ \\
\hline
\end{tabular}

평소에 자주 사용하는 숏폼 플랫폼은 다음과 같다. Shorts> Reels> Watch> TikTok> Quibi> MOMNET 순으로 나타나고 있었다. 유튜브와 인스타그램의 인기가 많은 것을 볼 수 있었 고, 페이스북과 틱톡이 다음으로 사용량이 많은 것을 확인할 수 있었다. Quibi의 사용자가 일부 나타나고 있었으나 그 수가 많지 않아 카카오스토리 등의 기타 의견에 포함하여 이 를 반영하였다.

플랫폼에 따른 콘텐츠 테마는 다음과 같다. 먼저 유튜브 플랫폼을 통해 많이 보는 콘텐 츠 테마의 결과는 다음과 같다.

[표 2] 솟폼 플랫폼 유형에 따른 콘텐츠 테마 교차 분석 결과(다중응답)

[Table 2] Results of Cross Analysis on Content Theme in Shortform Platform Type(Multiple Responses)

\begin{tabular}{c|c|c|c|c}
\hline 플랫폼 & 유튜브(Shorts) & 페이스북(Watch) & 인스타그램(Reel) & 틱톡(TikTok) \\
\hline 방송(짤) & $141(64.7 \%)$ & $82(48.2 \%)$ & $89(40.8 \%)$ & $52(23.9 \%)$ \\
\hline 게임 & $131(60.1 \%)$ & $54(31.8 \%)$ & $28(12.8 \%)$ & $66(30.3 \%)$ \\
\hline 먹방 & $91(41.7 \%)$ & $24(14.1 \%)$ & $27(12.4 \%)$ & $41(18.8 \%)$ \\
\hline 패션 & $48(22.0 \%)$ & $16(9.4 \%)$ & $100(45.9 \%)$ & $37(17.0 \%)$ \\
\hline 스포츠 & $66(30.3 \%)$ & $35(20.6 \%)$ & $40(18.3 \%)$ & $36(16.5 \%)$ \\
\hline 뉴스 & $33(15.1 \%)$ & $41(24.1 \%)$ & $30(13.8 \%)$ & $5(2.3 \%)$ \\
\hline 생활정보 & $39(17.9 \%)$ & $43(25.3 \%)$ & $65(29.8 \%)$ & $24(11.0 \%)$ \\
\hline 성인콘텐츠 & $7(3.2 \%)$ & $0(0.0 \%)$ & $38(17.4 \%)$ & $49(22.5 \%)$ \\
\hline 취미 & $65(29.8 \%)$ & $30(17.6 \%)$ & $76(34.9 \%)$ & $47(21.6 \%)$ \\
\hline 음악 & $148(67.9 \%)$ & $32(18.8 \%)$ & $57(26.1 \%)$ & $70(32.1 \%)$ \\
\hline 기타 & $20(9.2 \%)$ & $28(16.5 \%)$ & $30(13.8 \%)$ & $44(20.2 \%)$ \\
\hline 합계 & $218(100.0 \%)$ & $218(100.0 \%)$ & $218(100.0 \%)$ & $218(100.0 \%)$ \\
\hline
\end{tabular}

숏폼 플랫폼 유형에 따른 콘텐츠 테마 다중응답 결과는 [표 2]에서와 같이 차이를 나타 
내고 있는데 유튜브(Shorts)에서는 음악>방송(짤)>게임 순으로 콘텐츠를 활용하고 있었고, 페이스북(Watch)의 경우는 방송(짤)>게임>생활정보 순으로 나타나고 있었다. 인스타그램 (Reels)의 경우 패션>방송(짤)>취미의 콘텐츠를 주로 보는 것으로 나타나고 있었으며 틱톡 (TikTok)의 경우 음악>게임>방송(짤)이 많이 나타나고 있었다. 특이한 점은 페이이스북 (Watch)에서는 성인콘텐츠가 나타나고 있지 않은 반면 인스타그램(Reels)과 틱톡(TikTok)에 서는 성인콘텐츠를 많이 보고 있는 것으로 나타나고 있었다.

[표 3] 유튜브(Shorts)에서 즐겨보는 콘텐츠 테마 교차 분석 결과(다중응답)

[Table 3] Results of Cross-analysis of Favorite Content Themes on YouTube(Shorts)(Multiple Responses)

\begin{tabular}{|c|c|c|c|}
\hline 유형 성별 & 남 & 녀 & 합계 \\
\hline 방송(짤) & $57(26.1 \%)$ & $84(38.5 \%)$ & $141(64.7 \%)$ \\
\hline 게임 & $83(38.1 \%)$ & $48(22.0 \%)$ & $131(60.1 \%)$ \\
\hline 먹방 & $30(13.8 \%)$ & $61(28.0 \%)$ & $91(41.7 \%)$ \\
\hline 패션 & $15(6.9 \%)$ & $33(15.1 \%)$ & $48(22.0 \%)$ \\
\hline 스포츠 & $52(23.9 \%)$ & $14(6.4 \%)$ & $66(30.3 \%)$ \\
\hline 뉴스 & $21(9.6 \%)$ & $12(5.5 \%)$ & $33(15.1 \%)$ \\
\hline 생활정보 & $12(5.5 \%)$ & $27(12.4)$ & $39(17.9 \%)$ \\
\hline 성인콘텐츠 & $5(2.3 \%)$ & $2(0.9 \%)$ & $7(3.2 \%)$ \\
\hline 취미 & $28(12.8 \%)$ & $37(17.0 \%)$ & $65(29.8 \%)$ \\
\hline 음악 & $69(31.7 \%)$ & $79(36.2 \%)$ & $148(67.9 \%)$ \\
\hline 기타 & $9(4.1 \%)$ & $11(5.0 \%)$ & $20(9.2 \%)$ \\
\hline 합계 & $108(49.5 \%)$ & $110(50.5)$ & $218(100.0 \%)$ \\
\hline
\end{tabular}

유튜브(Shorts)를 통해 즐겨보는 콘텐츠 테마와 관련하여 음악(67.9\%)>방송(짤)(64.7\%)>게 임(60.1\%)로 많이 보는 것으로 나타나고 있었는데 세부적으로 남성의 경우 게임 $(38.1 \%)>$ 음악 $(31.7 \%)>$ 방송(짤) $(26.1 \%)$ 을 즐겨 보는 반면 여성의 경우 방송(짤) $(38.5 \%)>$ 음악 $(36.2 \%)>$ 먹방 $(28.0 \%)$ 순으로 나타나고 있는 것을 살펴볼 수 있었다. 이처럼 남녀의 차이가 분명한 것은 유튜브(Shorts)가 가지고 있는 플랫폼의 특성이 남녀의 성향에 따른 차이가 나타나고 있다는 것을 확인할 수 있는 것이라 할 수 있다.

[표 4] 페이스북(Watch)에서 즐겨보는 콘텐츠 테마 교차 분석 결과(다중응답)

[Table 4] Results of Cross-analysis of Favorite Content Themes on Facebook(Watch)(Multiple Responses)

\begin{tabular}{c|c|c|c}
\hline \multirow{2}{*}{ 유형 } & 성별 & 념 & 합 계 \\
\hline 방송(짤) & $47(27.6 \%)$ & $35(20.6 \%)$ & $82(48.2 \%)$ \\
\hline 게임 & $48(28.2 \%)$ & $6(3.5 \%)$ & $54(31.8 \%)$ \\
\hline 먹방 & $16(9.4 \%)$ & $8(4.7 \%)$ & $24(14.1 \%)$ \\
\hline 패션 & $11(6.5 \%)$ & $5(2.9 \%)$ & $16(9.4 \%)$ \\
\hline 스포츠 & $34(20.0 \%)$ & $1(0.6 \%)$ & $35(20.6 \%)$ \\
\hline 뉴스 & $20(11.8 \%)$ & $21(12.4 \%)$ & $41(24.1 \%)$ \\
\hline
\end{tabular}




\begin{tabular}{c|c|c|c}
\hline 생활정보 & $22(12.9 \%)$ & $21(12.4 \%)$ & $43(25.3 \%)$ \\
\hline 취미 & $25(14.7 \%)$ & $5(2.8 \%)$ & $30(17.6 \%)$ \\
\hline 음악 & $21(12.4 \%)$ & $11(6.5 \%)$ & $32(18.8 \%)$ \\
\hline 기타 & $10(5.9 \%)$ & $18(10.6 \%)$ & $28(16.5 \%)$ \\
\hline 합계 & $108(49.5 \%)$ & $110(50.5)$ & $218(100.0 \%)$ \\
\hline
\end{tabular}

페이스북(Watch)을 통해 즐겨보는 콘텐츠 테마와 관련하여 방송(짤)(48.2\%)>게임(31.8\%)> 생활정보(25.3\%)로 많이 보는 것으로 나타나고 있었는데 세부적으로 남성의 경우 게임 $(28.2 \%)>$ 방송(짤) $(27.6 \%)>$ 스포츠 $(20.0 \%)$ 을 즐겨 보는 반면, 여성의 경우 방송(짤) $(20.6 \%)>$ 뉴스(12.4\%), 생활정보(12.4\%) 순으로 나타나고 있는 것을 살펴볼 수 있었다. 이처럼 남녀 의 차이가 분명한 것은 페이스북(Watch)의 솟폼에서 얻는 정보는 특정한 정보에 있어 남 녀의 성향에 따른 차이가 나타나고 있다는 것을 확인할 수 있는 것이라 할 수 있다.

[표 5] 인스타그램(Reels)에서 즐겨보는 콘텐츠 테마 교차 분석 결과(다중응답)

[Table 5] Results of Cross-analysis of Favorite Content Themes on Instagram(Reels)(Multiple Responses)

\begin{tabular}{c|c|c|c}
\hline \multirow{2}{*}{ 유형별 } & 남 & 녀 & 합계 \\
\hline 방송(짤) & $40(18.3 \%)$ & $49(22.5 \%)$ & $89(40.8 \%)$ \\
\hline 게임 & $24(11.0 \%)$ & $4(1.8 \%)$ & $28(12.8 \%)$ \\
\hline 먹방 & $12(5.5 \%)$ & $15(6.9 \%)$ & $27(12.4 \%)$ \\
\hline 패션 & $33(15.1 \%)$ & $67(30.7 \%)$ & $100(45.9 \%)$ \\
\hline 스포츠 & $33(15.1 \%)$ & $7(3.2 \%)$ & $40(18.3 \%)$ \\
\hline 뉴스 & $11(5.0 \%)$ & $19(8.7 \%)$ & $30(13.8 \%)$ \\
\hline 생활정보 & $17(7.8 \%)$ & $48(22.0 \%)$ & $65(29.8 \%)$ \\
\hline 성인콘텐츠 & $27(12.4 \%)$ & $11(5.0 \%)$ & $38(17.4 \%)$ \\
\hline 취미 & $36(16.5 \%)$ & $40(18.3 \%)$ & $76(34.9 \%)$ \\
\hline 음악 & $29(13.3 \%)$ & $28(12.8 \%)$ & $57(26.1 \%)$ \\
\hline 기타 & $19(8.7 \%)$ & $11(5.0 \%)$ & $30(13.8 \%)$ \\
\hline 합계 & $108(49.5 \%)$ & $110(50.5)$ & $218(100.0 \%)$ \\
\hline
\end{tabular}

인스타그램(Reels)을 통해 즐겨보는 콘텐츠 테마와 관련하여 패션(45.9\%)>방송 (짤)(40.8\%)>취미(34.9\%)로 많이 보는 것으로 나타나고 있었는데 세부적으로 남성의 경우 방송(짤)(18.3\%)>취미(16.5\%)>스포츠, 패션(15.1\%)을 즐겨 보는 반면 여성의 경우 패션 $(22.0 \%)>$ 방송(짤)(22.5\%)>생활정보(22.0\%) 순으로 나타나고 있는 것을 살펴볼 수 있었다. 인스타그램(Reels)의 경우 이처럼 남녀의 차이가 분명한 것은 솟폼에서 얻는 정보는 특정 한 정보에 있어 조금 더 분명하게 관심 분야의 영상이 차이를 보이고 있음을 확인할 수 있었다.

[표 6] 틱톡(TikTok)에서 즐겨보는 콘텐츠 테마 교차 분석 결과(다중응답)

[Table 6] Results of Cross-analysis of Favorite Content Themes on TikTok(Multiple Responses)

\begin{tabular}{c|c|c|c}
\hline 성별 & 남 & 녀 & 합계 \\
\hline 융형(짱) & $21(9.6 \%)$ & $31(14.2 \%)$ & $52(23.9 \%)$ \\
\hline 게임 & $43(19.7 \%)$ & $23(10.6 \%)$ & $66(30.3 \%)$ \\
\hline
\end{tabular}




\begin{tabular}{c|c|c|c}
\hline 먹방 & $16(7.3 \%)$ & $25(11.5 \%)$ & $41(18.8 \%)$ \\
\hline 패션 & $5(2.3 \%)$ & $32(14.7 \%)$ & $37(17.0 \%)$ \\
\hline 스포츠 & $32(14.7 \%)$ & $4(1.8 \%)$ & $36(16.5 \%)$ \\
\hline 뉴스 & $5(2.3 \%)$ & $0(0 \%)$ & $5(2.3 \%)$ \\
\hline 생활정보 & $11(5.0 \%)$ & $13(6.0 \%)$ & $24(11.0 \%)$ \\
\hline 성인콘텐츠 & $25(11.5 \%)$ & $24(11.0 \%)$ & $49(22.5 \%)$ \\
\hline 취미 & $22(10.1 \%)$ & $25(11.5 \%)$ & $47(21.6 \%)$ \\
\hline 음악 & $35(16.1 \%)$ & $35(16.1 \%)$ & $70(32.1 \%)$ \\
\hline 기타 & $27(12.4 \%)$ & $17(7.8 \%)$ & $44(20.2 \%)$ \\
\hline 합계 & $108(49.5 \%)$ & $110(50.5 \%)$ & $218(100.0 \%)$ \\
\hline
\end{tabular}

틱톡(TikTok)을 통해 즐겨보는 콘텐츠 테마와 관련하여 음악 $(32.1 \%)>$ 게임 $(30.3 \%)>$ 방송 (짤)(23.9\%)순으로 많이 보는 것으로 나타나고 있었는데 세부적으로 남성의 경우 게임 (19.7\%)>음악(16.1\%)>스포츠(14.7\%)을 즐겨 보는 반면 여성의 경우 음악(16.1\%)>패션 $(14.7 \%)>$ 방송(짤) $(14.2 \%)$ 순으로 나타나고 있는 것을 살펴볼 수 있었다. 틱톡(TikTok)의 경 우 이처럼 다른 플랫폼에 비해 성인콘텐츠 정보를 많이 보는 것으로 나타나고 있어 이러 한 점은 특이할 만한 점이라고 할 수 있다.

\section{2 가설 2의 결과}

솟폼 콘텐츠의 이용 동기와 이용 만족에 관한 요인분석 결과는 [표 7] 같이 나타나고 있다. 우선 독립변수는 재미 요인, 유용성, 용이성으로 분류가 되었고, 신뢰도 검증에 있어 신뢰수준 0.7 이상의 결과를 보이고 있었다.

종속변수인 이용만족에 대한 요인분석 결과도 [표 8]과 같이 나타나고 있는데, 이용지속 변수 요인 6 개, 신뢰성 요인 4개, 구전의도 3 개로 나타났다. 신뢰도 검정에 있어 0.7 이상 의 신뢰도를 나타냈다.

[표 7] 디지털 미디어 플랫폼의 이용동기 요인분석 결과

[Table 7] Result of Factor Analysis on the Use Gratification of Digital Media Platform

\begin{tabular}{|c|c|c|c|c|}
\hline \multicolumn{2}{|c|}{ 질문문항 } & factor1 & factor2 & factor3 \\
\hline \multirow{11}{*}{ 독립변수 } & 재미1 & .848 & & \\
\hline & 재미2 & .818 & & \\
\hline & 재미3 & .769 & & \\
\hline & 재미4 & .636 & & \\
\hline & 유용성 1 & & .873 & \\
\hline & 유용성 2 & & .772 & \\
\hline & 유용성 3 & & .699 & \\
\hline & 유용성 4 & & .696 & \\
\hline & 용이성 1 & & & .838 \\
\hline & 용이성2 & & & .629 \\
\hline & 용이성 3 & & & .618 \\
\hline \multicolumn{2}{|c|}{ 고유값(eigen value) } & 3.014 & 2.847 & 1.966 \\
\hline
\end{tabular}




\begin{tabular}{c|c|c|c}
\hline 설명 총분산(\%) & 27.404 & 25.882 & 17.870 \\
\hline 누적 총분산(\%) & 27.404 & 53.286 & 71.156 \\
\hline Reliability Coefficient( $\alpha)$ & .846 & .838 & .715 \\
\hline
\end{tabular}

[표 8] 디지털 미디어 플랫폼의 이용만족 요인분석 결과

[Table 8] Result of Factor Analysis on the Use Satisfaction of Digital Media Platform

\begin{tabular}{|c|c|c|c|c|}
\hline \multicolumn{2}{|c|}{ 질문문항 } & factor1 & factor2 & factor3 \\
\hline \multirow{13}{*}{ 종속변수 } & 이용지속1 & .916 & & \\
\hline & 이용지속2 & .892 & & \\
\hline & 이용지속3 & .868 & & \\
\hline & 이용지속4 & .784 & & \\
\hline & 이용지속5 & .705 & & \\
\hline & 이용지속6 & .655 & & \\
\hline & 신뢰성 1 & & .890 & \\
\hline & 신뢰성2 & & .828 & \\
\hline & 신뢰성3 & & .822 & \\
\hline & 신뢰성 4 & & .789 & \\
\hline & 구전의도1 & & & .877 \\
\hline & 구전의도2 & & & .875 \\
\hline & 구전의도3 & & & .835 \\
\hline \multicolumn{2}{|c|}{ 고유값(eigen value) } & 4.360 & 3.239 & 2.317 \\
\hline \multicolumn{2}{|c|}{ 설명 총분산(\%) } & 29.069 & 21.591 & 15.447 \\
\hline \multicolumn{2}{|c|}{ 누적 총분산(\%) } & 29.069 & 50.660 & 66.107 \\
\hline \multicolumn{2}{|c|}{ Reliability Coefficient $(\alpha)$} & .930 & .903 & .914 \\
\hline
\end{tabular}

[표 9] 이용불편성의 신뢰도 검증

[Table 9] Verification Reliability in the Inconvenience of Use

\begin{tabular}{c|c}
\hline 항목 & Reliability Coefficient $(\alpha)$ \\
\hline 유해정보가 많아 보기 불편하다 & \multirow{2}{*}{.835} \\
광고가 많아 짜증난다 & \\
\hline 쓸모없는 정보가 너무 많다 & \\
\hline
\end{tabular}

이용 불편성에 대한 항목의 타당성을 위해 신뢰도 검증을 한 결과 .835 로 유의미한 결과 가 나타났다. 가설 2 에 재미( $\beta=.499, \mathrm{p}<.001)$, 용이성 ( $\beta=.255, \mathrm{p}<.001)$, 유용성 $(\beta=.157, \mathrm{p}<.01)$ 과 이용 지속 에 관한 연구결과는 [표 10]에 나타난 것처럼 통계적으로 유의미한 값을 보이며 가설이 채택되었다. 즉 재미와, 유용성, 용이성은 모두 솟폼 플랫폼을 사용하는데 있어 중요한 변수로 작용한다는 것을 살펴볼 수 있었다. 또한 이용 지속과 관련하여 재미가 가장 중 요하고, 용이성과 유용성 순으로 나타나고 있는 것을 볼 때 이용 지속에 있어 재미 요소 가 중요한 요인으로 살펴볼 수 있었다. 
[표 10] 사용지속과 관련된 회귀분석결과

[Table 10] Results of Regression related to Persistence of Use

\begin{tabular}{lcccccccc}
\hline 종속변수 & 독립변수 & $\mathrm{B}$ & $\mathrm{Std} . \mathrm{E}$ & $\beta$ & $t$ & $p$ & 공차 & $\mathrm{ViF}$ \\
\hline & Constant & .255 & .187 & & 1.400 & .000 & & \\
\cline { 2 - 9 } & 재미 & .498 & .053 & .499 & 9.413 & $.000^{* * *}$ & .893 & 1.444 \\
\cline { 2 - 5 } 숑지속 & 용이성 & .267 & .058 & .255 & 4.573 & $.000^{* * *}$ &. .622 & 1.608 \\
\cline { 2 - 8 } & 유용성 & .154 & .056 & .157 & 2.779 & $.006^{* *}$ &. .609 & 1.642 \\
\hline $\mathrm{R}^{2}=.585, \mathrm{Adj}^{2}=.579, \mathrm{~F}=100.469$ & & & & & & \\
$* p<.05, * * p<.01, * * * p<.001$ & & & & & & & \\
Durbin-Watson $=1.866$ & & & & & & & & \\
\hline
\end{tabular}

또한 신뢰성에 관한 연구결과는 [표 11]에 나타난 것처럼 용이성( $\beta=.392, \mathrm{p}<.001)$, 유용성( $\beta$ $=.374, \mathrm{p}<.001)$, 재미 ( $\beta=.183, \mathrm{p}<.01)$ 가 통계적으로 유의미한 값을 보이며 가설이 채택되었다. 즉 재미와, 유용성, 용이성은 모두 숏폼 플랫폼을 사용하는데 있어 중요한 변수로 작용한다 는 것을 살펴볼 수 있었다. 이중에 용이성이 신뢰성에는 가장 중요한 요인으로 볼 수 있 으며, 재미는 음의 값을 나타나고 있었는데 신뢰성에 있어서는 재미요소가 너무 높을 경 우 부정적인 영향을 줄 수 있다는 것을 의미하는 것이라고 해석할 수 있다.

[표 11] 신뢰성과 관련된 회귀분석결과

[Table 11] Results of Regression related to Reliability

\begin{tabular}{|c|c|c|c|c|c|c|c|c|}
\hline 종속변수 & 독립변수 & B & Std.E & $\beta$ & $t$ & $p$ & 공차 & VIF \\
\hline \multirow{4}{*}{ 신뢰성 } & Constant & 1.004 & .222 & & 4.527 & .000 & & \\
\hline & 용이성 & .401 & .071 & .392 & 5.632 & $.000^{* * *}$ & .622 & 1.608 \\
\hline & 유용성 & .360 & .068 & .374 & 5.318 & $.000^{* * *}$ & .609 & 1.642 \\
\hline & 재미 & -.179 & .065 & -.183 & -2.778 & $.006^{* *}$ & .693 & 1.608 \\
\hline $\begin{array}{l}\mathrm{R}^{2}=.356, A \\
* p<.05, * * \\
\text { Durbin-Wa }\end{array}$ & $\begin{array}{l}\mathrm{j} \mathrm{R}^{2}=.347, \mathrm{~F} \\
<.01, * * * p< \\
\text { on }=2.138\end{array}$ & 466 & & & & & & \\
\hline
\end{tabular}

구전의도와 관련된 회귀분석 결과는 [표 12]와 같다. 구전의도와 관련하여 용이성만 통 계적으로 유의미한 결과값을 나타내고 있었고( $\beta=.426, \mathrm{p}<.001)$, 유용성과 재미는 유의미하지 않 은 결과값을 나타내고 있었다. 이는 쉽게 얻고 사용할 수 있는 정보에 대해서 구전의도 를 가지고 있는 것으로 해석할 수 있는 것으로 빠르고 쉽게 정보에 대한 공유를 할 수 있다는 것을 의미한다.

[표 12] 구전의도와 관련된 회귀분석결과

[Table 12] Results of Regression related to Intention of Viral

\begin{tabular}{|c|c|c|c|c|c|c|c|c|}
\hline 종속변수 & 독립변수 & B & Std.E & $\beta$ & $t$ & $p$ & 공차 & VIF \\
\hline \multirow{4}{*}{ 구전의도 } & Constant & .265 & .296 & & .894 & .372 & & \\
\hline & 용이성 & .574 & .095 & .426 & 5.761 & $.000^{* * *}$ & .622 & 1.608 \\
\hline & 유용성 & .114 & .090 & .094 & 1.265 & .207 & .609 & 1.642 \\
\hline & 재미 & .078 & .086 & .064 & .906 & .366 & .693 & 1.444 \\
\hline \multicolumn{9}{|c|}{$\begin{array}{l}\mathrm{R}^{2}=.272, \operatorname{Adj} \mathrm{R}^{2}=.262, \mathrm{~F}=26.716 \\
* p<.05, * * p<.01, * * * p<.001\end{array}$} \\
\hline
\end{tabular}




\section{3 가설 3 의 결과}

솟폼 콘텐츠를 이용함에 있어 이용 불편과 이용 만족에 대한 결과는 [표 13]과 같다.

[표 13] 이용 불편과 이용만족의 회귀분석 결과

[Table 13] Results of Regression related to Persistence of Use and Use Satisfaction

\begin{tabular}{|c|c|c|c|c|c|c|c|}
\hline & B & Std.E & $\beta$ & $t$ & $p$ & $\operatorname{Adj} R^{2}$ & $F$ \\
\hline Constant & 1.924 & .275 & & 6.986 & .000 & \multirow{2}{*}{.014} & \multirow{2}{*}{4.082} \\
\hline 구전의도 & .157 & .078 & .136 & 2.020 & $.045^{*}$ & & \\
\hline Constant & 3.018 & .225 & & 13.398 & .000 & \multirow{2}{*}{.005} & \multirow{2}{*}{2.058} \\
\hline 이용지속 & .091 & .064 & .097 & 1.435 & .153 & & \\
\hline Constant & 2.298 & .221 & & 10.404 & .000 & \multirow{2}{*}{.001} & \multirow{2}{*}{1.219} \\
\hline 신뢰성 & 0.69 & .063 & .075 & 1.104 & .271 & & \\
\hline${ }^{*} p<.05$ & & & & & & & \\
\hline
\end{tabular}

이용 불편과 이용 만족에 있어 구전 의도만 통계적으로 유의미한 결과값을 나타내고 있었다 $(\beta=.136, p<.05)$. 콘텐츠 이용에 있어 이용 불편은 지속적인 콘텐츠 사용과 만족에 영 향을 미칠 수 있다는 점에서 이용 불편에 대한 결과를 측정하였다 이는 이용 불편에 대 한 것을 다른 사람들에게 구전을 통해 이를 공유하겠다는 것으로 해석할 수 있다.

\section{5. 결론 및 논의}

숏폼 콘텐츠 유형과 이용 동기가 콘텐츠 소비에 미치는 영향에 대한 연구를 위해 부 산시의 남녀 고등학생들을 대상으로 조사 분석한 결과를 요약하면 다음과 같다.

먼저 본 연구에서 정의한 첫 번째 가설에 대한 결론을 요약하면 숏폼 플랫폼의 유형이 콘텐츠 테마에 영향을 미치는 것으로 나타났다. 우선, 솟폼 플랫폼은 유튜브(Shorts), 인스 타그램 (Reels), 페이스북(Watch), 틱톡, 네이버블로그(Moment) 순으로 이용 정도가 높게 나타났다.

성별에 따른 플랫폼 이용정도를 살펴보면, 남학생은 페이스북, 여학생은 인스타그램의 플랫폼 이용이 상대적으로 높게 나타났다. 이 점에서 남녀간의 플랫폼 이용의 가장 큰 차이를 보였다. 또한, 플랫폼에 따른 콘텐츠테마 이용은 다음과 같다. 유튜브(Shorts)는 음 악, 방송, 게임이 비슷한 수준으로 높게 나타났으며 페이스북(Watch)은 방송(짤), 인스타그 램(Reels)은 패션과 방송(짤), 틱톡은 음악과 게임이 높게 나타났다. 이와 같은 결과는 플 랫폼의 유형에 최적화된 콘텐츠 테마일수록 많이 소비된다는 결과로 해석된다. 한편, 플 랫폼에 따른 콘텐츠 테마의 이용에 있어서 성별의 차이가 있었다. 특히, 페이스북과 인스 타그램에서 남녀 차이가 분명한 이유는 성별에 따라 선호하는 플랫폼과 콘텐츠 테마간의 연관성이 반영된 결과로 보인다. 따라서, 숏폼 플랫폼을 중심으로 광고집행 시 성별, 플 랫폼 유형, 콘텐츠 테마를 함께 고려할 필요가 있다. 그리고 틱톡의 경우 다른 플랫폼에 비해 성인콘텐츠 정보가 많이 노출되는 점은 틱톡이 가볍고 다소 선정적인 콘텐츠 때문 에 급성장한 배경을 보여준다.

두 번째 숏폼 콘텐츠의 이용 동기에 따른 이용 만족(이용 지속, 신뢰성, 구전의도)은 차이가 있을 것이라는 가설에 대해서는 남녀 고등학생의 경우 재미, 유용성, 용이성 모두 이용 만족에 영향을 주는 것으로 나타났다. 특히 용이성이 이용 만족에서 가장 중요하게 
작용했으며 재미요소가 너무 높을 경우 오히려 부정적인 영향을 주는 것으로 나타났다. 이러한 결과는 이용동기중에서 콘텐츠의 재미 요소보다는 콘텐츠의 이용 편리성이 이용 만족에 더 크게 작용한다는 점을 보여준다. 그리고 구전의도에 있어서도 용이성만 유의 미한 결과를 나타났다. 이는 쉽고 빠르게 콘텐츠를 공유할 수 있는 점을 가장 중요하게 여기는 것으로 해석된다.

세 번째 숏폼 콘텐츠의 이용 불편성은 이용 만족(이용지속, 신뢰성, 구전의도)에 차이 가 있을 것이라는 가설에 대해 요약하면, 이용 불편과 이용 만족에 있어서 구전의도만 유의미한 결과를 나타났다. 즉, 남녀 고등학생 사용자 입장에서 콘텐츠를 이용하기에는 다소 불편하더라도 공유할 가치나 의미가 있다고 생각하면 적극적으로 공유하는 것으로 보인다.

본 연구의 함의는 10 대 고등학생들이 가장 즐겨 이용하는 솟폼 플랫폼 유형에 따른 차이를 살펴본 것이다. 특히, 틱톡이 급성장함에 따라 거의 모든 주요 플랫폼에서 서비스 하고 있는 시점에서 숏폼 콘텐츠의 차이를 분석함으로써 향후 본격화되고 있는 숏폼 콘 텐츠 시장을 전망할 수 있었다. 그리고, 솟폼 플랫폼에 따라 성별, 테마별로 이용의 차이 를 발견할 수 있었으며 이는 광고전략 수립 시 중요한 가이드 라인을 제시할 것이다. 소 셜미디어 콘텐츠 플랫폼에서 솟폼 콘텐츠를 이용한 마케팅 전략은 $\mathrm{MZ}$ 세대에게 브랜드를 인지하는데 중요한 영향을 미칠 수 있을 것으로 보인다. 기존의 광고와는 다른 유형의 메시지 전달방식은 플랫폼에 따라 더욱더 진화할 것으로 예측된다. 향후에는 플랫폼 유 형별로 테마를 면밀하게 분석함으로써 보다 풍부한 실무적인 함의를 제공할 수 있도록 연구를 이어가기를 기대한다. 본 연구의 한계는 다음과 같다. 표본 선정에 있어 편의표집 을 통해 자료를 수집해서 한정된 자료 분석이 이뤼졌다는 점이다. 이러한 점을 보완하여 연구에 반영해야 할 것으로 생각된다. 향후 연구를 통해 플랫폼 유형에 따른 다양한 차 이를 살펴봄으로써 각 플랫폼이 가지고 있는 유형별 특성이 어떻게 나타는지 실무적 차 원의 분석이 이뤄질 수 있어야 할 것이다.

\section{6. 감사의 글}

이 논문은 2021 년도 고신대학교 학술연구비 지원을 받아 수행된 연구입니다

\section{References}

[1] Short Form Contents Trend, Mezzo Media Report, (2019)

[2] Jin Lee, Aspect of Storytelling in Korean Web drama, Humanities Contents, (2015), No.38, pp.241-260, DOI: 10.18658/humancon.2015.09.38.241

[3] E. Katz, J. G. Blumler, M. Gurevitch, Uses and gratifications research, Public Opinion Quarterly, (1973), Vol.37, No.4, pp.509-523, DOI: https://doi.org/10.1086/268109

[4] Kim Jae Hwi, Hong Jae Wook, Motivation and Website Behaviors of Internet Users, The Korean Journal of Consumer and Advertising Psychology, (2000), Vol.1, No.2, pp.25-46.

[5] Jay G. Blumler, The Role of Theory in Uses and Gratifications Studies, Communication Research, (1979), Vol,6, No,1, pp.9-36, DOI: https://doi.org/10.1177/009365027900600102

[6] E. Katz, M. Gurevitch, H. Haas, On the use of the mass media for important things, American Sociological Review, (1973), Vol.38, No.2, pp.164-181, DOI: https://doi.org/10.2307/2094393 
[7] Kim Kyung Jin, An Dae Chun, Lifestyle Segmentation of Smartphone Users and Its Impact on the Usage of Newspaper Applications and Attitude Toward Advertising, Korea Design Forum, (2014), No.42, pp.55-66, DOI: $10.21326 / \mathrm{ksdt} .2014 . .42 .005$

[8] N. F. Barrett, J. Schulkin, A Neurodynamic Perspective on Musical Enjoyment: The Role of Emotional Granularity, Frontiers in Psychology, (2017), Vol.8, No.13, pp.1-6, DOI: https://doi.org/10.3389/fpsyg.2017.02187

[9] M. Pittman, Sheehan Kim, Sprinting a media marathon: Uses and gratifications of binge-watching television through Netflix, First Monday, (2015),Vol.20, No.10, DOI: https://doi.org/10.5210/fm.v20i10.6138

[10] J. H. Do, J. H. Kim, The Influence of Facebook Ad Type on Advertising Effect Persuasion Knowledge Model and Technology Acceptance Model, The Korean Journal of Advertising and Public Relations, (2012), Vol.14, No.2, pp.300330, UCI: G704-001035.2012.14.2.009

[11] B. C. Jung, J. O. Koo, The Effects of SNS Messenger's Traits and SNS Information Charateristics on the Purchase Intention, Korean Corporation Management Review, (2013), Vol.20, No.2, pp.251-272, UCI: G704002085.2013.20.2.006

[12] B. J. Barbin, W. R. Darden, M. Grifin, Work and/or Fun: Measuring Hedonic and Utiltarian Shoping Value, Journal of Consumer Research, (1994), Vol.20, No.4, pp.644-656, DOI: https://doi.org/10.1086/209376

[13] K. Henderson, M. Glancy, S. Little, Putting the fun into physical activity, Journal of Physical Education, Recreation \& Dance, (1999), Vol.70, No.8, pp.43-45, DOI: https://doi.org/10.1080/07303084.1999.10605706

[14] E. S. Orr, M. Sisic, C. Ross, M. G. Simmering, J. M. Arseneault, R. R. Orr, The Influence of Shyness on the Use of Facebook in an Undergraduate Sample, Cyberpsychology, Behavior, and Social Networking, (2009), Vol.12, No.3, pp.337-340, DOI: $10.1089 / \mathrm{cpb} .2008 .0214$

[15] G. C. Moore, I. Benbasat, Development of an Instrument to Measure the Perceptions of Adopting an Information Technology Innovation, Information System Research, (1991), Vol.2, No.3, pp.192-233, DOI: https://doi.org/10.1287/isre.2.3.192 